\title{
The Use of Chromium and Acid-Detergent Lignin in Complete Rations as Indicators of the Fecal Excretion Rate in the Ruminant Animal ${ }^{1}$
}

\author{
José A. Arroyo-Aguilú and Joe L. Evans ${ }^{2}$
}

\section{INTRODUCTION}

For many years there has been an increasing interest in utilizing inert, nonabsorbed materials to determine the digestibility of nutrients in the feeds of nonruminant and ruminant animals. These index substances, intended to be nontoxic and indigestible to the animal, are being used as indicators of digestibility by means of ratio techniques. Chromic oxide $(23,27)^{3}$ and lignin $(13,21)$ are two of the most used markers in digestibility studies.

Chromic oxide, often administered in capsule form and used as an external indicator (31), has been observed to present a wide range of concentrations in its excretion pattern during a 24-hour interval (16). The close agreement between the total collection and the chromic oxide method indicated that accurate coefficients of digestibility may be obtained by using this indicator mixed uniformly into a complete ration for ruminant animals $(19,23,26,30)$.

Lignin, on the other hand, is a natural constituent of the ration utilized frequently as an internal marker by the ratio technique $(1,21,22)$. At times the low recovery in the feces (12) makes its use questionabie. Porter (29) suggested that lignin as measured by the acid-pepsin technique undergoes more extensive changes than the acid-detergent lignin (L), introduced by Van Soest (35). As a result, $L$ may act as a more valid marker than other lignin forms and chromium (Cr).

Feed dry matter has been divided by Van Soest (36) on the basis of solubility into two fractions: cellular contents or neutral-detergent solubles

1 Paper of the Journal Series, New Jersey Agricultural Experiment Station, Rutgers University, New Brunswick, N. J. Data are taken in part from a thesis submitted to the Graduate Faculty in partial fulfillment of the requirements for the degree of Doctor of Philosophy.

2 Assistant Nutritionist, Animal Husbandry Department, Agricultural Experiment Station, Mayagüez Campus, University of Puerto Rico, Río Piedras, P. R. and Professor of Nutrition, Animal Sciences Department, Rutgers University, New Brunswick, N. J., respectively. The senior author wishes to express his sincere appreciation to former Director Arturo Roque, Agricultural Experiment Station, University of Puerto Rico, for his interest in granting a leave of absence $t, 0$ pursue graduate work.

Italic numbers in parentheses refer to Literature Cited, pp. 673. 
(NDS) and cell-wall constituents (CWC). The NDS fraction is completely available and is composed of soluble carbohydrates, lipids, most proteins and other water-soluble matter. The CWC or total fiber fraction (\$7) is partially and nonuniformly available and consists of hemicellulose (HCD), cellulose (C) and $L(85)$.

This study reports the evaluation of $\mathrm{Cr}$ and $\mathrm{L}$ as index substances for determining digestibility of ration nutrients using growing steers consuming complete, low-fiber rations.

\section{PROCEDURE}

Intake and fecal data, collection and processing of samples, and weighing of animals were conducted as outlined (3). Growing Jersey steers were fed once daily. The rations were formulated from corn cobs, beet pulp, corn-starch, soybean oil, molasses, minerals, vitamins, choline chloride, several nitrogen $(\mathrm{N})$ sources, and with or without $\mathrm{Cr}$ as chromic oxide (3).

Chemical analyses were made on all feed, fecal and fecal grab samples by the methods in the indicated references: $\mathrm{Cr}$, calcium (Ca) and magnesium (Mg) (2), dry matter and Kjeldahl nitrogen (4) and CWC (37). Acid-detergent fiber (ADF) and $L$ were determined essentially as outlined by Van Soest (35), except that $75 \mathrm{ml}$. of the detergent solution were added to a 0.5-g. sample. For the determination of $\mathrm{C}$ in feed and fecal samples, a slight modification of the Crampton and Maynard (10) method was used. Regression equations to predict C ( 8 ) were employed, and HCD was represented by CWC minus ADF.

Statistical analyses were performed according to Snedecor and Cochran (32).

\section{TRIAL I}

The objective was to study the rate of recovery in the feces of ration $\mathrm{L}$ and $\mathrm{Cr}$ during depletion and repletion with $\mathrm{Cr}$ in steers consuming complete low-fiber feeds.

During a 10-week period, four steers, ranging in weight from 223 to $400 \mathrm{~kg}$., were fed a mixture of rations 11 and $14(3)$. For the first 3 weeks and the last 4 weeks of the 10 -week period, the total ration contained 0.58 to 0.62 percent $C r$. The $L$ content for the 10 -week period was 3.5 to 4.9 percent. Chromium was not fed during the second 3 -week interval. Beginning with the third week, total fecal collections were made on days 6 and 7 of each subsequent week until the termination of the trial for a total of eight collections.

During a 4-week period, three steers, ranging in weight from 244 to 336 $\mathrm{kg}$, were fed a chromium-free mixture of rations 11 and 14 (3). However, for the first day of the last week, the total ration contained 0.63 percent 
$\mathrm{Cr}$, and the $\mathrm{I}$ ranged from 3.7 to 4.2 percent. During the last week total fecal collections were carried out daily.

TRIAT, II

The objective was to study the rate of recovery of $\mathrm{Cr}$ and $\mathrm{L}$ in complete feeds consumed by growing ruminant animals.

Digestibility trials totaling 140 collections using steers, ranging in weight from 134 to $643 \mathrm{~kg}$., in previous trials I, II and III (3) were conducted. Trials I and II consisted of four consecutive 21-day feeding periods, with total collection of feces during the last 3 days of each period. In trial III the 3-day collections started on the 7th, 23d and 39th day of each of the five 42-day periods. One hundred twenty eight of the 140 total collections were used in $\mathrm{Cr}$ recovery determinations, and 39 of the 60 total collections in trial III $(8)$ were used in $\mathrm{L}$ recovery determinations. The rations contained 0.19 to 0.54 percent $C r$ and 1.3 to 5.2 percent $L$.

TRIAL III

This trial was conducted to determine the excretion patterns of nutrients, $\mathrm{L}$ and $\mathrm{Cr}$ during a 24-hour period for complete feeds by growing steers.

During previous trials I and II, after the animals were adjusted to their rations for a minimum of 42 days, 80 fecal grab samples (16 steers for 5 times each within 24 hours) were collected from steers ranging in weight from 152 to $626 \mathrm{~kg}$. These rations contained 0.19 to 0.21 percent $\mathrm{Cr}$ and 1.6 to 3.1 percent $\mathrm{L}$.

The steers were fed once daily at 11 a.m., with the five fecal grab samples taken at 4.5-hour intervals after feeding. The grab samples were taken either directly from the rectum or from the last defecation, if feces was voided voluntarily at collection time.

\section{RESULTS, DISCUSSION AND, CONCLUSION}

\section{TRLAL I}

The rates of recovery of $\mathrm{Cr}$ and $\mathrm{L}$ are presented graphically in figures 1 and 2.

\section{Depletion and Repletion of $\mathrm{Cr}$ in the Feces}

Chromium was recovered in the feces after a 7-day depletion period to the extent of $1.9 \pm 0.3$ percent, and recovery continued to decrease to $0.54 \pm 0.02$ percent after a 21 -day depletion period (fig. 1).

When $\mathrm{Cr}$ was supplied in the diet for only one day, the amount racovered in the feces on the seventh day was $1.1 \pm 0.2$ percent. A maximum concentration of $29.8 \pm 0.9$ percent $\mathrm{Cr}$ was recovered on the second day. 
Kallai et al. (19) reported that, after chromic oxide was fed to wethers, 15 to 20 percent appeared in the feces in 24 hours and nearly all after 8 days (98.2 percent). The accumulation of the $\mathrm{Cr}$ recovered after the 7-and the 21-day depletions totaled $85.5 \pm 7.2$ percent and $90.5 \pm 2.4$ percent.

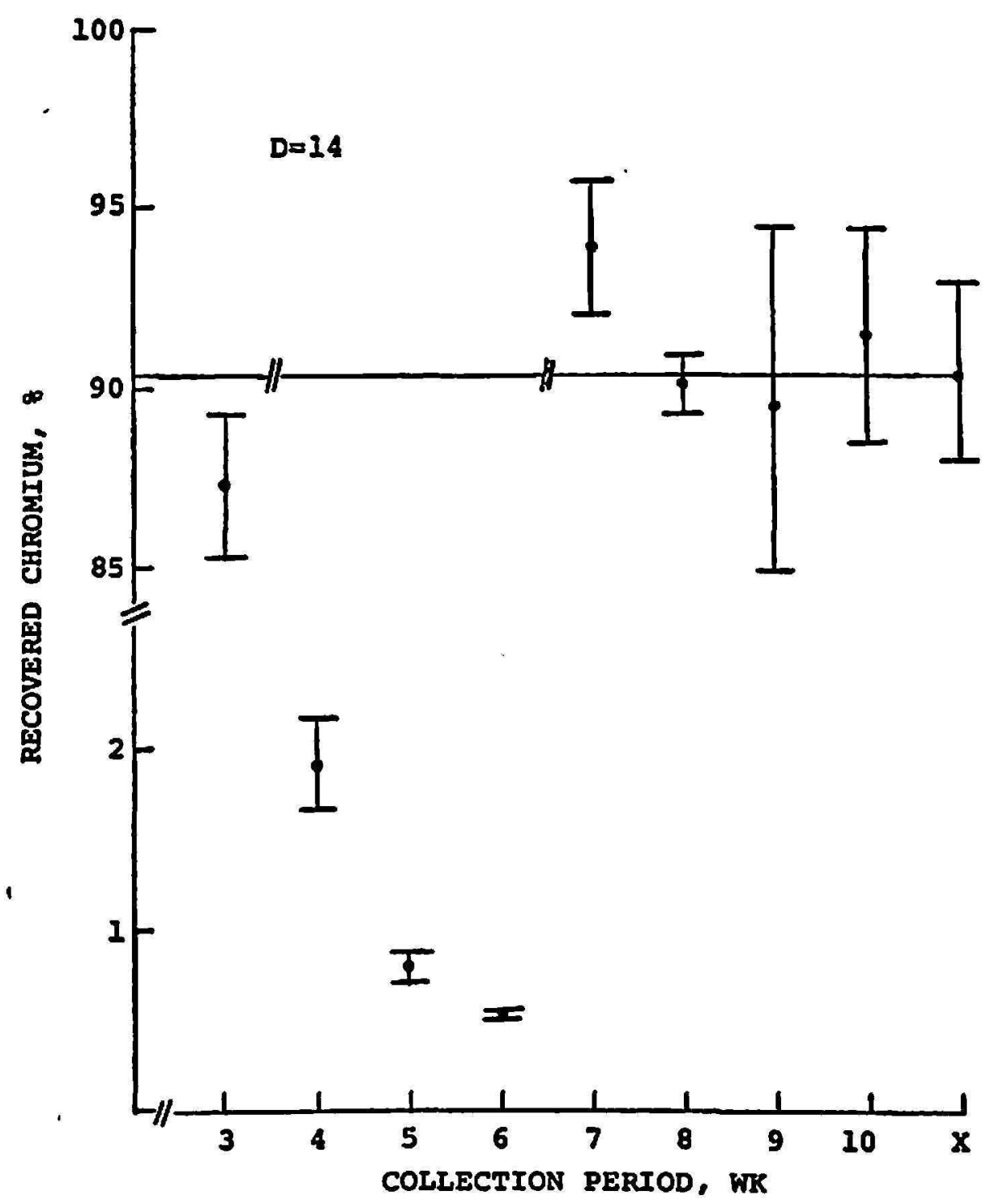

Fra. 1.-Recovery rate (mean \pm SE) of chromium during depletion and repletion periods, with Tukey's $D$ for $P<0.05 . X$ is mean for repletion samples.

From the 8th to the 21st day, the amount of $\mathrm{Cr}$ recovered in the feces was small (5.0 percent), thus showing that, within a 7-day period 85.5 percent of the total $\mathrm{Cr}$ in complete feeds was eliminated. Johnson et al. (18) indicated that chromic oxide concentration in the feces of wethers fed pelleted alfalfa rations containing chromic oxide impregnated in paper and chromil oxide powder appeared to reach near maximum levels 72 hours after its administration. The same trend was observed in these trials, where 
most of the ration $\mathrm{Cr}$ was recovered in the feces during the first 5 days $(82.3 \pm 6.8$ percent $)$.

Hardison et al. (17), working with forages, reported that 3 to 7 days may be required for chromic oxide to reach a stable level in the feces. Crampton and Lloyd (9) observed that, when chromic oxide was mixed with some portion of the ration, a minimum period of 5 days was required after the initial administration before the concentration of the indicator reached a constant or maximum level in the feces. They also suggested that, when

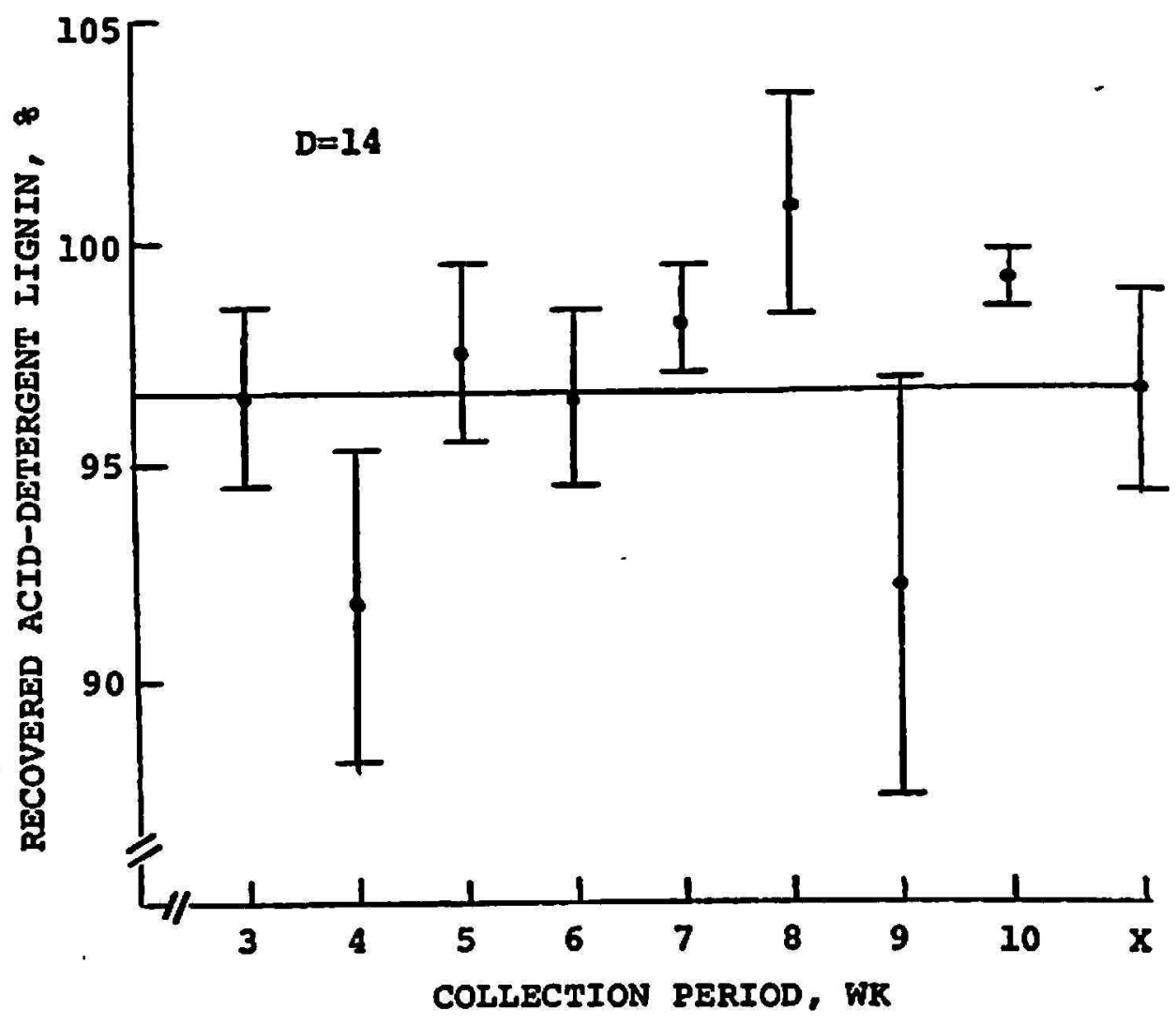

Fig. 2.-Recovery rate (mean $\pm \mathrm{SE}$ ) of acid-detergent lignin during a 10-week period, with Tukey's D for $P<0.05 . X$ is mean for weekly samples.

chromic oxide was fed in a concentrated form, the rate of excretion of chromic oxide was slower and a minimum period of 9 days seemed necessary to bring the fecal indicator level to a maximum.

Chromium was recovered to the extent of $93.9 \pm 1.9$ percent (fig. 1) after a diet containing 0.6 percent $\mathrm{Cr}$ was fed for a 7 -day period, with a mean of $90.5 \pm 2.5$ percent for a 4 -week repletion period. The value, 93.9 \pm 1.9 percent, was the maximum $\mathrm{Cr}$ recovery value obtained during the 4-week $\mathrm{Cr}$ repletion period. No statistical differences $(P<0.05)$ were found among the weekly means for recovered $\mathrm{Cr}$, indicating that a steady state had been reached during the first week of repletion. However, at 
the beginning of repletion, a residual of $0.54 \pm 0.02$ percent $\mathrm{Cr}$ in the feces was present. Anderson et al. (1), Barnicoat (5), Clanton (6), Hardison et al. (17), Johnson et al. (18), and Moore (28) have reported from 80 to 95 percent recovery of dietary chromic oxide in feces.

The Cr, not eliminated in the feces, may have been absorbed from the digestive tract or may have been adsorbed to the mucosal walls of the digestive tract. Deinum et al. (11) concluded that the small nonexcreted part of the chromic oxide was absorbed. McGuire et al. (27) could offer no explanation for the low chromic oxide recovery value, 94.2 percent, obtained when feeding a 0.5-percent chromic oxide complete ration to growing steers. MacKenzie et al. (25) administered a dose of radioactive chromate to rats similar to the amount that they would receive per day while drinking water containing 2 p.p.m. Cr. They determined that, after feeding radioactive chromate for 1 day, the liver showed a maximal uptake of about 1 percent whereas kidney and blood contained 0.1 to 0.2 percent. However, a decreased concentration of $\mathbf{C r}$ with time was observed. Deinum et al. (11) indicated that traces of chromic oxide were absorbed in parts of the digestive tract and could be found in liver, lymph glands and kidneys. Observations made in this laboratory of characteristic dark coloration of the rumen wall of slaughtered steers consuming rations containing chromic oxide for extended periods suggested that the indicator was adsorbed.

\section{Rate of Recovery of $L$ in the Feces}

It has been suggested that L (35) may be a more valid marker because it undergoes less extensive change than the lignin prepared by the acid pepsin technique (29).

Lignin is a naturally-occurring constituent; however, it has not been identified as a chemical entity of definite composition. Furthermore, Sullivan (83) suggested that the methods of lignin analysis were empirical and not standardized in an acceptable form. As a result, use of lignin as an indicator in digestibility studies with forage has been considered unreliable. Nonetheless, Forbes and Garrigus (15), Kane et al. (21) and Swift et al. (84) utilized the lignin ratio techniques in feed studies with apparent success.

In complete pelleted rations, the crude lignin method of Ellis et al. (14) resulted in low coefficients of digestibility. Kane et al. (20) also obtained low coefficients calculated by the crude lignin technique. Elam and Davis (12) showed that an average of only 87.1 percent of the crude lignin fed was recovered in the feces.

Wher $\mathrm{L}$ was used as an indicator over a 10-week period, $96.6 \pm 2.3$ percent $L$ was recovered (fig. 2) in contrast to a value of 104 percent obtained with all forage rations (8). Similarly, during a 7-day period, $96.7 \pm$ 
0.6 percent $L$ was recovered, ranging from $94.3 \pm 0.5$ percent to $98.3 \pm$ 0.3 percent. Anderson et al. (1) also obtained a recovery rate for $L$ of 96.2 \pm 2.2 percent in concentrate mixtures during a 17-day period. No statistical differences $(P<0.05)$ were obtained among weekly means, thus showing (fig. 2) a steady state of $L$ excretion.

As indicated by Colburn and Evans (7), ADF represents essentially the sum of C and L. Van Soest (86) reported that $L$ itself, in contrast to the structural carbohydrates, appears uniform in the Lucas (24) test, indicating an availability not significantly different from zero. As a result, $L$ may be considered a suitable indicator for the ratio techniques in complete feeds, especially when it may be essentially recovered by utilizing the techniques of Van Soest (35).

TRIAL II

Digestibility trials were conducted for extended periods as indicated (S), and the rates of recovery of $\mathrm{Cr}$ and $\mathrm{L}$ were determined.

Rate of Recovery of $\mathrm{Cr}$ in the Feces

It was determined that $96.0 \pm 2.1$ percent of the $\mathrm{Cr}$ was recovered at the end of the first 21-day period. Slightly lower values of $91.8 \pm 1.6$, $95.6 \pm 1.8$ and $95.2 \pm 1.6$ percent were obtained at the end of the next three consecutive 21-day periods, respectively. However, no statistical differences $(P<0.05)$ were found among period means, thus showing that a steady state existed at the end of period 1, with more uniformity developing during periods 3 and 4.

Results were similar in a second trial. Recovery rates of $\mathrm{Cr}$ were $92.6 \pm$ 1.8, $94.4 \pm 1.4,97.6 \pm 1.7$ and $96.6 \pm 1.4$ percent in successive 21-day periods. No statistical differences $(P<0.05)$ were found among period means. A mean $\mathrm{Cr}$ recovery value of $95.4 \pm 0.6$ percent was obtained for both trials.

Similar results were again obtained per period in a third trial (\$) (89.6 \pm $0.9,93.1 \pm 2.0,88.8 \pm 1.9,94.4 \pm 1.8$ and $95.4 \pm 1.3$ percent), with no statistical differences $(P<0.05)$ among period means. A mean Cr recovery value of $92.3 \pm 0.9$ percent was obtained. An overall $\mathrm{Cr}$ recovery of 94.0 \pm 0.5 percent was obtained for the three trials, in contrast to recovery rates of $90.5 \pm 2.5$ percent (fig. 1) and $85.5 \pm 5.9$ percent in short-term feeding trials. Anderson et al. (1) obtained Cr recovery values of $84.8 \pm$ 1.4 percent and $83.8 \pm 8.0$ percent for 17-day periods. Similar results were obtained by Lassiter et al. (23) and McGuire et al. (27). However, Kane et al. (21) recovered chromic oxide in the feces at the rate of 99.9 percent during a 9-day period, with a 10-day preliminary period. Although it has been indicated by this study and by others $(9,17)$ that a level of 85 percent 
or more of $\mathrm{Cr}$ excretion in the feces was reached after 3 to 7 days, the saturation of the adsorption sites may take longer than 3 weeks.

\section{Rate of Recovery of $L$ in the Feces}

A total of 39 entire collections out of 60 were used to calculate $L$ recovery in growing steers consuming complete feeds. The remaining fecal collections were not utilized because wood shavings bedding was consumed by some steers. A grand mean recovery for $\mathrm{L}$ of $94.1 \pm 1.0$ percent was obtained, comparing favorably with means of $96.6 \pm 2.3$ percent (fig. 2) and $96.7 \pm 0.6$ percent recovered $L$ obtained in 10 -week and 7-day periods. Although similar recoveries were obtained under varying conditions of $L$ intake, the level of $\mathrm{L}$ intake and the length of the pre-collection feeding period are the most important considerations when the indicator, $L$, is used. Yang and Thomas (38) reported that the coefficients of digestibility obtained by using chromic oxide and $L$ as indicators were very similar, except in the rumen where chromic oxide reduced values.

\section{TRIAI III}

The patterns of excretion of nutrients, $\mathrm{Cr}$ and $\mathrm{L}$ per unit of indicator at 4.5-hour intervals during a 24-hour period, are presented graphically in figures 3 and 4 . No statistical differences $(P<0.05)$ were found among grab-sampling times in rates of excretion of nutrients per unit of indicator. Similar results were obtained by McGuire et al. (27) with chromic oxide and protein excretion rates.

\section{Indicator-to-indicator Ratio}

The rate of excretion of $\mathrm{Cr}$ (fig. 3) and $\mathrm{L}$ (fig. 4) was not affected significantly $(P<0.05)$ by sampling period in relation to feeding time, though L-to-Cr ratio showed a decreasing but not a significant $(P<0.05)$ trend as sampling time progressed in a 24-hour period.

An increasing trend in Cr-to-L ratio was observed as sampling time progressed during a 24-hour interval. Johnson et al. (18) suggested that, in relation to lignin, chromic oxide is passed out more rapidly from the anterior portion and less rapidly from the posterior portion of the tract, effecting a build-up or concentration of the indicator in the latter portion. McGuire et al. (27) obtained no significant differences due to sampling time or feeding frequency in chromic oxide concentration in the feces.

These data indicate that the difference in grab sampling times was minimal when the $\mathrm{Cr}$ and $\mathrm{L}$ ratio techniques were used to determine digestibility. Utilizing the Ellis et al. (14) method for lignin, Elam and Davis (12) arrived at the same conclusions. In this study, the hourly variation in $\mathrm{Cr}$ and $L$ excretion patterns tended to be minimal in complete feeds. 


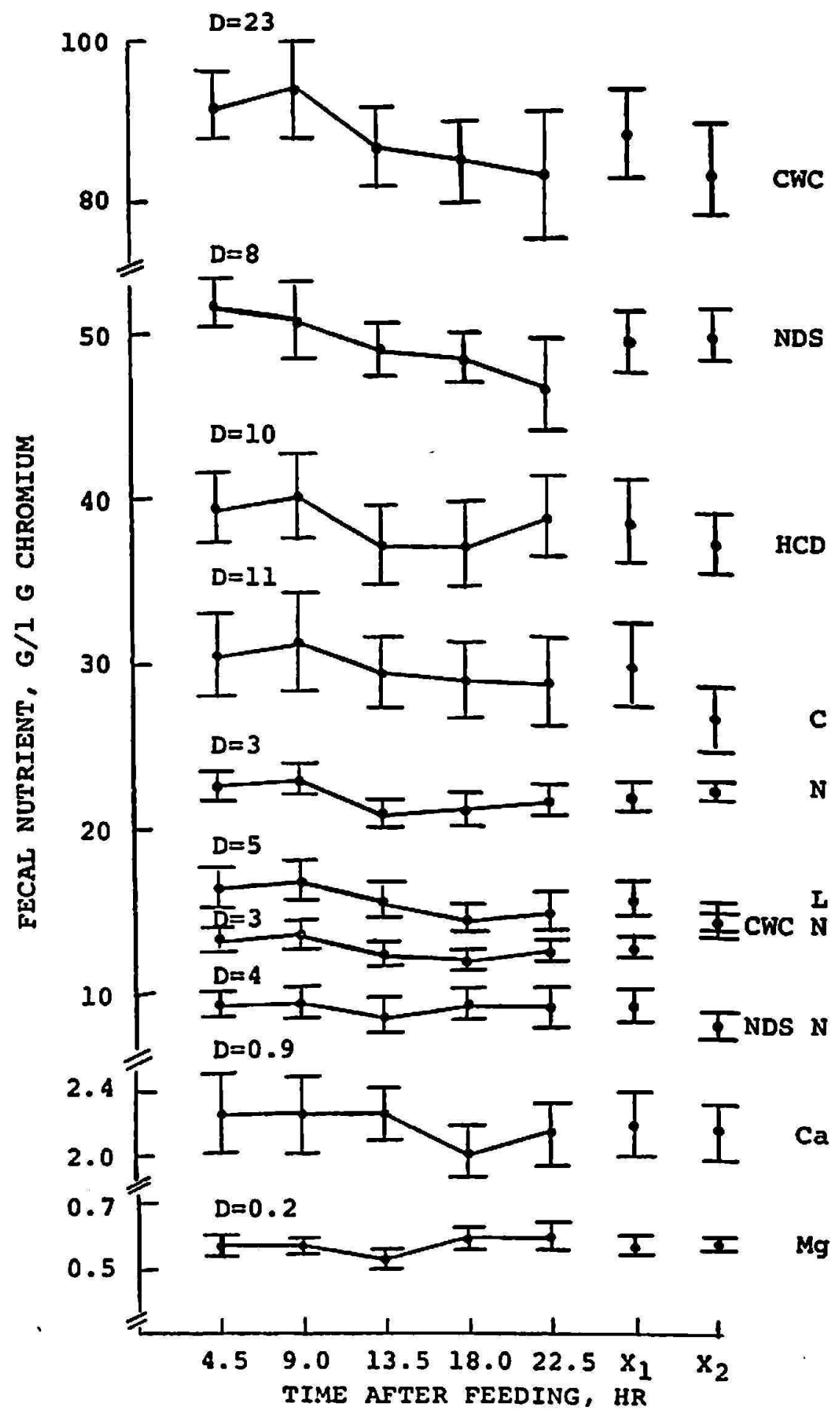

Fro. 3.-Rate of excretion of nutrient (mean $\pm \mathrm{SE}$ ) per $1 \mathrm{~g}$. of chromium during a 24-hour interval, with Tukey's $D$ for $P<0.05 . X_{1}$ is mean for five grab samples; $X_{2}$, total collections.

\section{Nutrient-to-indicator Ratio}

The fibrous fractions (CWC, HCD, $\mathrm{C}$ and CWC N) -to-Cr ratios (fig. 3) tended to decrease as time-after-feeding sampling increased, indicating that the greater part of the nutrients were eliminated more quickly. 


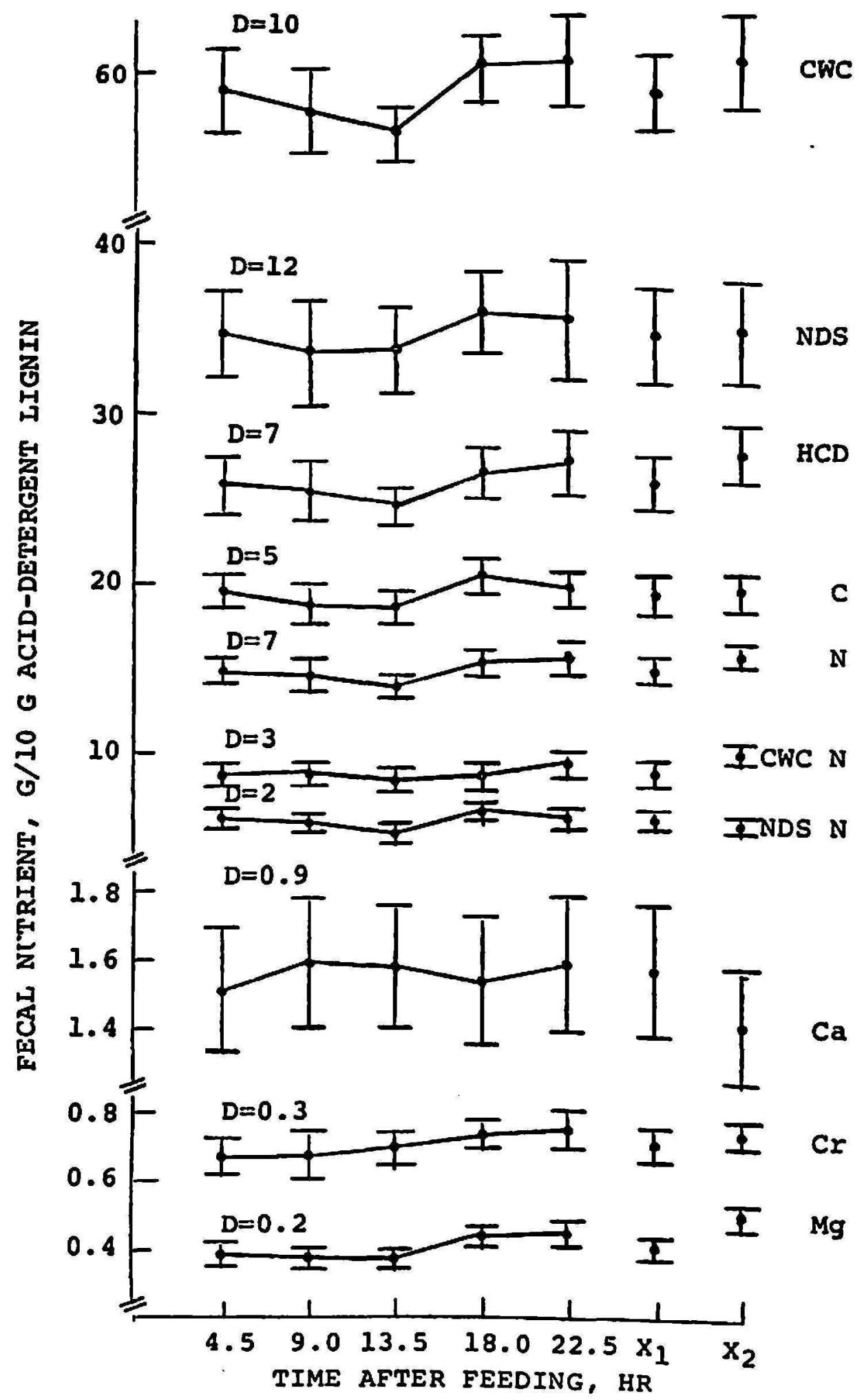

Frc. 4. -Rate of excretion of nutrient (mean $\pm \mathrm{SE}$ ) per $10 \mathrm{~g}$. of acid-detergent lignin during a 24-hour interval, with Tukey's D for $P<0.05$. $X_{1}$ is mean of five grab samples; $X_{2}$, total collections. 
The mean values for the grab samples $\left(X_{1}\right)$ were closer to sampling period 3 (13.5 hours after feeding). However, the excretion values from the total collection trial $\left(X_{2}\right)$ corresponding to the grab sampling period were in all cases, except for CWC N, lower than the fecal grab sample mean. The total collections agreed more closely with sampling periods 4 or 5 (18 or 22.5 hours after feeding) in the CWC and HCD fractions.

The nonfibrous fractions (NDS, N, NDS N, Ca and $\mathrm{Mg}$ ) -to-Cr ratios (fig. 3) followed the same pattern as the fibrous fractions. There seemed to be a tendency for a larger nutrient fraction to be excreted sooner with a uniform quantity of Cr. In all nonfibrous fractions, except NDS, a tendency of the nutrients to increase at sampling periods 3 or 4 (13.5 or 18 hours after feeding) was evident.

The excretion of the fibrous fractions-to-L ratio (fig. 4) followed a somewhat reverse pattern from the $\mathrm{Cr}$ ratio, possibly demonstrating the slower excretion of nutrients per $\mathrm{L}$. The mean value tended to be related to sampling periods 3 or 4 . The total collection value was higher than the mean value and agreed better with sampling period 5 .

The excretion of the nonfibrous fractions-to- $L$ ratios (fig. 4) followed a similar pattern to that of the fibrous fractions. The total collection values were either equal to or higher than the mean values, except for $\mathrm{Ca}$ and NDS $N$ excretion. In a similar study, Johnson et al. (18) obtained a very similar rate of flow of $\mathrm{Ca}$ and chromic oxide, indicating that the flow of Ca through the various sections of the tract paralleled the flow of chromic oxide.

Estimation of Digestion Coefficients from the Ratio Techniques and from Total Collections

Digestion coefficients were calculated from the $\mathrm{Cr}$ and $\mathrm{L}$ indicator methods and from the total collection data (tables 1 and 2). No significant differences $(P<0.05)$ among digestion coefficients were obtained between means of grab samples and total collections, indicating that $\mathrm{Cr}$ and $\mathrm{L}$ ratio techniques may be utilized in digestibility determinations. Longer periods of $\mathrm{Cr}$ intake may provide a better estimation of recovery, resulting in more reliable results.

Recovery data tends to show that $L$ may be a more valid indicator than $\mathrm{Cr}$. Recovered $\mathrm{Cr}$ appeared lower than recovered $\mathrm{L}$ and a larger variation in digestion coefficients was found for $\mathrm{Cr}$.

\section{SUMMARY}

Chromium (Cr) and acid-detergent lignin (L) were evaluated as index substances for determining digestibility of complete, low-fiber rations with 
TABLE 1.-Mean intake and fecal excretion data of nutrients per unit of indicator

\begin{tabular}{|c|c|c|c|c|c|c|}
\hline \multirow[t]{2}{*}{$\begin{array}{c}\text { Chemical } \\
\text { component }\end{array}$} & \multicolumn{2}{|c|}{ Feed intake? } & \multicolumn{4}{|c|}{ Fecal output } \\
\hline & G.N/1 B. Cr & G.N/10 B.L & G.N/1 B. Cr & G.N/10 g. L & G.N/1 B. Cr & G.N/110 g. L \\
\hline \multicolumn{7}{|l|}{ Nitrogen X 6.25} \\
\hline Total & $85.4 \pm 3.5$ & $66.2 \pm 4.9$ & $21.8 \pm 0.9^{2}$ & $14.8 \pm 0.8^{3}$ & $22.0 \pm 0.7^{3}$ & $15.6 \pm 0.7^{8}$ \\
\hline NDS & $58.9 \pm 3.6$ & $45.5 \pm 3.8$ & $9.1 \pm 1.0$ & $5.9 \pm 0.6$ & $7.9 \pm 0.8$ & $5.7 \pm 0.5$ \\
\hline CWC & $26.5 \pm 1.2$ & $20.7 \pm 1.8$ & $12.7 \pm 0.7$ & $8.9 \pm 0.7$ & $14.1 \pm 0.4$ & $9.9 \pm 0.6$ \\
\hline NDS & $360.4 \pm 5.3$ & $272.5 \pm 16.5$ & $49.4 \pm 1.9$ & $34.6 \pm 2.8$ & $49.7 \pm 1.6$ & $34.9 \pm 3.1$ \\
\hline CWC & $183.9 \pm 5.0$ & $139.4 \pm 5.9$ & $88.0 \pm 5.7$ & $58.9 \pm 2.2$ & $82.6 \pm 4.7$ & $60.8 \pm 2.8$ \\
\hline Hemicellulose & $118.3 \pm 3.3$ & $90.7 \pm 5.1$ & $38.5 \pm 2.4$ & $25.9 \pm 1.6$ & $37.2 \pm 1.8$ & $27.7 \pm 1.7$ \\
\hline Cellulose & $47.3 \pm 2.2$ & $35.2 \pm 1.1$ & $29.8 \pm 2.6$ & $19.4 \pm 1.1$ & $26.4 \pm 2.0$ & $19.5 \pm 1.2$ \\
\hline Lignin & $14.7 \pm 0.9$ & - & $15.5 \pm 1.1$ & - & $14.2 \pm 1.0$ & - \\
\hline Chromium & - & $0.78 \pm 0.05$ & - & $0.70 \pm 0.05$ & - & $0.73 \pm 0.04$ \\
\hline Calcium & $3.09 \pm 0.19$ & $2.38 \pm 0.20$ & $2.19 \pm 0.20$ & $1.56 \pm 0.19$ & $2.16 \pm 0.20$ & $1.40 \pm 0.17$ \\
\hline Magnesium & $0.88 \pm 0.04$ & $0.67 \pm 0.05$ & $0.57 \pm 0.03$ & $0.40 \pm 0.03$ & $0.58 \pm 0.01$ & $0.49 \pm 0.04$ \\
\hline
\end{tabular}

1 Data are included for 16 steers. Grams nutrient per one gram chromium expressed as G. N/1 g. Cr.

2 Mean of 80 fecal grab samples (5 per total collection).

aean of 16 total collections corresponding to fecal grab sampling. 
growing steers. The rate of recovery of ration $\mathrm{Cr}$ was studied during depletion and repletion of the indicator.

Total fecal collections were carried out for 7 days after a 1-day period of $\mathrm{Cr}$ intake. Recovered $\mathrm{Cr}$ for the 7-day period amounted to $85.5 \pm 7.2$ percent with a value of $82.3 \pm 6.8$ percent for the first 5 days, with a maximum amount of 30 percent on the second day. During the 21-day depletion following a 21-day repletion, fecal $\mathrm{Cr}$ decreased rapidly for the

TaBle 2.-Mean digestion coefficients calculated from grab sample and total collection data

\begin{tabular}{|c|c|c|c|c|c|}
\hline \multirow{3}{*}{ Chemical component } & \multicolumn{5}{|c|}{ Digestion coefficientsI } \\
\hline & \multicolumn{2}{|c|}{ Mean" } & \multicolumn{2}{|c|}{ Means } & \multirow{2}{*}{$\begin{array}{l}\text { Mean' } \\
\text { Percent }\end{array}$} \\
\hline & Percent & Percent & Percens & Percent & \\
\hline \multicolumn{6}{|l|}{ Nitrogen } \\
\hline Total & $74.5^{5}$ & $77.7^{\circ}$ & $74.2^{5}$ & $76.5^{6}$ & $74.8 \pm 1.2$ \\
\hline NDS & 84.5 & 86.9 & 86.5 & 87.4 & $84.7 \pm 1.9$ \\
\hline CWC & 52.3 & 57.8 & 47.1 & 52.3 & $48.8 \pm 3.2$ \\
\hline NDS & 86.3 & 87.3 & 86.2 & 87.2 & $87.0 \pm 0.4$ \\
\hline CWC & 52.2 & 57.7 & 55.1 & 56.3 & $56.1 \pm 2.1$ \\
\hline Hemicellulose & 67.4 & 71.5 & 68.6 & 69.4 & $68.9 \pm 1.9$ \\
\hline Cellulose & 37.1 & 45.0 & 44.1 & 44.6 & $45.0 \pm 3.1$ \\
\hline Lignin & $105.4^{7}$ & - & $96.6^{7}$ & - & - \\
\hline Chromium & - & $90.0^{7}$ & - & $94.0^{7}$ & $88.8 \pm 1.17$ \\
\hline Calcium & 29.1 & 34.5 & 30.1 & 41.2 & $33.0 \pm 3.5$ \\
\hline Magnesium & 35.2 & 40.3 & 34.1 & 26.9 & $37.0 \pm 2.2$ \\
\hline
\end{tabular}

1 No significant difference $(P<0.05)$ within nutrients.

2 Data included for 80 fecal grab samples (5 per total collection) using the indicator ratio technique.

Data included for 16 total collections corresponding to fecal grab samples using the indicator ratio technique.

- Means for digestibility and recovery data calculated directly from total intake and output dats.

Calculated from $\mathrm{g}$. nutrients $/ 1 \mathrm{~g}$. Cr.

- Calculated from $\mathrm{g}$. nutrients/10 g. L.

7 Recovery data.

first 7 days and continued to decrease to $0.54 \pm 0.02$ percent at the end of the depletion. During 7-day and 10-week periods, $\mathrm{L}$ was recovered to the extent of $96.7 \pm 0.5$ and $96.6 \pm 2.3$ percent, respectively.

Recovered $\mathrm{Cr}$ amounted to $94.4 \pm 0.5$ percent in long-term trials and to $90.5 \pm 2.5$ percent in short-term trials. In long-term trials, $L$ was recovered to the extent of $94.1 \neq 1.0$ percent. No statistical differences $(P<0.05)$ were found among grab-sampling times or between grab samples and the total collection samples in rates of excretion of nutrients per unit of indicator. 
It was suggested that the differences in grab-sampling times were minimal when either $\mathrm{Cr}$ or $\mathrm{L}$ indicator techniques were used to determine digestibility. Recovery data tend to show that $\mathrm{L}$ is a valid marker and has the desirable characteristic of being a constituent of ruminant feedstuffs.

\section{RESUMEN}

El cromo (2) y la lignina (35) se evaluaron como indicadores en novillos castrados para determinar la digestibilidad de raciones completas bajas en fibra. Durante los períodos de agotamiento y repleción del cromo, que fue incorporado en la ración en forma de óxido crómico, se estudio el porcentaje de recuperación en las heces. Las heces se recogieron durante 7 días consecutivos, después de sumistrársele cromo por 1 día a los novillos.

El cromo recuperado en los 7 días ascendió a $85.5 \pm 7.2$ por ciento, con un valor de $82.3 \pm 6.8$ por ciento en los primeros 5 días. Durante el período de agotamiento de 21 días, que siguió a un periodo de repleción de 21 días, el cromo fecal se redujo rápidamente durante los primeros 7 días y luego gradualmente hasta bajar a $0.54 \pm 0.02$ por ciento a los 21 días. La recuperación de la lignina fue de $96.7 \pm 0.6$ por ciento y $96.6 \pm$ 2.3 por ciento durante períodos de 7 dias y 10 semanas, respectivamente.

La recuperación del cromo fue de $94.0 \pm 0.5$ por ciento y $90.5 \pm 2.5$ por ciento durante períodos largos y cortos, respectivamente. Durante los períodos largos, la recuperación de la lignina fue de $94.1 \pm 1.0$ por ciento. No se encontraron diferencias significativas $(P<0.05)$ entre las muestras de heces tomadas cada 4.5 horas durante 24 horas o entre éstas y las muestras de la colección total usándose como criterio las unidades de nutrimentos excretados por unidad del indicador (figuras 2 y 3 ).

Se concluyó que las diferencias en digestibilidad durante el ciclo de excreción fecal fueron mínimas al usarse el cromo o la lignina como indicadores. El porcentaje de recuperación de los indicadores tiende a indicar que la lignina es un indicador más ventajoso y posee la buena característica de ser un componente de los alimentos.

\section{LITERATURE CITED}

1. Anderson, M. J., Oleson, W. H., and Stoddard, G. E., The influence of concentrate: forage ratios on digestibility using indicator techniques, abs., J. Dairy Sci. 60: 989, 1967. 2. Anonymous, Analytical Methods for Atomic Absorption Spectrophotometry,
Perkin-Elmer Corp., Norwalk, Conn., 1966.

3. Arroyo-Aguilu, J. A., and Evans, J. L., Nutrient digestibility of complete, lowfiber rations in the ruminant animal, J. Dairy Sci. (In press.)

4. Assoniation of Official Agricultural Chemists, Official Methods of Analysis, 10th ed., Washington, D. C., 1965.

5. Barnicoat, C. R., Estimation of apparent digestibility coefficients by means of an inert "reference-substance", N.Z.J. Sci. Technol. 27: 202-12, 1945. 
6. Clanton, D. C., Variation in chromic oxide methods of determining digestibility of hand-fed beef cattle rations, J. Anim. Sci. 21: 214-8, 1962.

7. Colburn, M. W., and Evans, J. L., Chemical composition of the acid-detergent fraction of orchardgrass, alfalfa and mixed forages, Abstr., J. Dairy Sci. 48: $1557-8,1965$.

8. Colburn, M. W., Evans, J. L., and Ramage, C. H., Apparent and true digestibility of forage nutrients by ruminant animals, $J$. Dairy Sci. $61: 1450-7,1968$.

9. Crampton, E. W., and Lloyd, L. E., Studies with sheep on the use of chromic oxide as an index of digestibility of ruminant rations, $J$. Nutr. 45: 319-27, 1951.

10. Crampton, E. W., and Maynard, L. A., The relation of cellulose and ligning content to the nutritive value of animal feeds, $J . N u t r .15: 383-95,1938$.

11. Deinum, B., Immink, H. J., and Deijs, W. B., The excretion of chromium sesquioxide in faeces by cows after administration of $\mathrm{Cr}_{2} \mathrm{O}_{8}$-containing paper, Jaarb. Inst. Biol. Scheik. Onderz. Landbgewass 188: 123-9, 1962.

12. Elam, C. J., and Davis, R. E., Lignin excretion by cattle fed a mixed ration, $J$. Anim. Sci. 20: 484-6, 1961.

13. Elam, C. J., Reynolds, P. J., Davis, R. E., and Everson, D. O., Digestibility studies by means of chromic oxide, lignin, and total collection techniques with sheep, J. Anim. Sci. 81: 189-92, 1962.

14. Ellis, G. H., Matrone, G., and Maynard, L. A., A 72 percent $\mathrm{H}_{2} \mathrm{SO}_{4}$ method for the determination of lignin and its use in animal nutrition studies, $J$. Anim. Sci. b: 285-97, 1946.

15. Forbes, R. M., and Garrigus, W. P., Application of a lignin ratio technique to the determination of the nutrient intake of grazing animals, J. Anim. Sci. 7: 373-82, 1948.

16. Hardison, W. A., Engel, R. W., Linkous, W. N., Sweeney, H. C., and Graf, G. C., Fecal chromic oxide concentration in 12 dairy cows as related to time and frequency of administration and to feeding schedule, $J$. Nutr. 58: 11-7, 1956.

17. Hardison, W. A., Linkous, W. N., Engel, R. W., and Graf, G. C., Observations on the use of chromic oxide for estimating the fecal output of dairy animals, J. Dairy Sci. 48: 346-52, 1959.

18. Johnson, D. E., Dinusson, W. E., and Bolin, D. W., Rate of passage of chromic oxide and composition of digesta along the alimentary tract of wethers, $J$. Anim. Sci. 88: 499-505, 1964.

19. Kállai, L., Till, F., Keresztes, M., and Tangl, H., Digestibility trials with wethers: barium sulfate and chromic oxide as markers, Kiserletugyi Koslemenyelc 54B: 15-39, 1961 (from Nut. Abs. Revs. 39: 848, 1963).

20. Kane, E. A., Ely, R. E., Jacobson, W. C., and Moore, L. A., A comparison of various digestion trial techniques with dairy cattle, $J$. Dairy Sci. \$6: 325-33, 1953.

21. Kane, E. A., Jacobson, W. C., and Moore, L. A., A comparison of techniques used in digestibility studies with dairy cattle, $J$. Nutr. 41: 583-96, 1950.

22. Kane, E. A., Jacobson, W. C., and Moore, L. A., Diurnal variation in the excretion of chromium oxide and lignin, J. Nutr. 47: 263-73, 1952.

23. Lassiter, J. W., Alligood, V., and McGaughey, C. H., Chromic oxide as an index of digestibility of all-concentrate rations for sheep, J. Anim. Sci. 25: 44-7, 1966.

24. Lucas, Jr., H. L., Smart, Jr., W. W. G., Cipolloni, M. A., and Gross, H. D., Relations between digestibility and composition of feeds and foods, S-45 Report, N. C. St. Coll. Raleigh, N. C., 1961. 
25. MaKenzie, R. D., Anwar, R. A., Byerrum, R. U., and Hoppert, C. A., Absorption and distribution of $\mathrm{Cr}^{51}$ in the albino rat, Arch. Biochem. Biophys. \%8: 200-5, 1959.

26. McCoy, G. C., Olson, H. H., and Reed, A., Diurnal excretion pattern and digestibility of three complete feeds, $J$. Dairy Sci. 49: 211-4, 1966.

27. McGuire, R. L., Bradley, N. W., and Little, C. O., Effects of frequency of feeding on excretion of chromic oxide, crude protein and gross energy and on nutrient digestibility by steers, J. Anim. Sci. 25: 185-91, 1966.

28. Moore, J. H., Diurnal variations in the composition of the faeces of pigs on diets containing chromic oxide, Brit. J. Nutr. 11: 273-88, 1957.

29. Porter, P., Lignin as an inert marker in studies of ruminant digestion, Abstr., Proc. Nutr. Soc. 84: VI-VII, 1965.

30. Putnam, P. A., Elam, C. J., and Everson, D., Comparison of chromic oxide and conventional methods in digestion trials using steers fed pelleted rations, USDA., ARS., Tech. Bull. 1312, 1964.

31. Smith, A. M., and Reid, J. T., Use of chromic oxide as an indicator of fecal output for the purpose of determining the intake of pasture herbage by grazing cows, J. Dairy Sci. 38: 515-24, 1955.

32. Snedecor, G. W., and Cochran, W. G., Statistical Methods, 6th. ed., Ia. St. Coll. Press, Ames, Iowa, 1962.

33. Sullivan, J. T., Evaluation of forage crops by chemical analysis, A Review, Agron. J. 54: 511-5, 1962.

34. Swift, R. W., Thacker, E. J., Black, A., Bratzler, J. W., and James, W. H., Digestibility of rations for ruminants as affected by proportion of nutrients, J. Anim. Sci. 6: 432-44, 1947.

35. Van Soest, P. J., Use of detergents in the analysis of fibrous feeds, II, A rapid method for determination of fiber and lignin, J. Assoc. Off. Agr. Chem. 46: 829-35, 1963.

36. Van S Sest, P. J., Development of a comprehensive system of feed analysis and its application to forages, $J$. Anim. Sci. 26: 119-28, 1967.

37. Van Soest, P. J., and Wine, R. H., Use of detergents in the analysis of fibrous feeds, IV, Determination of plant cell-wall constituents, J. As8oc. Off. Anal. Chem. 50: 50-5, 1967.

38. Yang, M. G., and Thomas, J. W., Absorption and secretion of some organic and inorganic constituents and the distribution of these constituents throughout the alimentary tract of young calves, $J$. Nutr. 87: 444-58, 1965. 